\title{
The GROSMarin Experiment: Three Dimensional Crustal Structure of the North Ligurian Margin From Refraction Tomography and Preliminary Analysis of Microseismic Measurements
}

5 Jean-Xavier Dessa ${ }^{1}$, Soazig Simon ${ }^{1}$, Marjorie Lelièvre ${ }^{1}$, Marie-Odile Beslier ${ }^{1}$, Anne Deschamps ${ }^{1}$, Nicole Béthoux ${ }^{1}$, Stefano Solarino ${ }^{2}$, Françoise Sage ${ }^{1}$, Elena Eva ${ }^{2}$, Gabriele Ferretti ${ }^{3}$, Olivier Bellier ${ }^{4}$, Claudio $\mathrm{Eva}^{3}$

${ }^{1}$ Geoazur, Univ. P. et M. Curie, Univ. Nice Sophia Antipolis, Obs. Côte d'Azur - Quai de la Darse, BP 48, 06235

10 Villefranche/Mer, France.

${ }^{2}$ Istituto Nazionale di Geofisica e Vulcanologia, c/o Dip.Te.Ris - Viale Benedetto XV 5, 16132, Genova, Italy.

${ }^{3}$ Univ. Genova, Dip.Te.Ris - Viale Benedetto XV 5, 16132, Genova, Italy.

${ }^{4}$ CEREGE, Univ. P. Cézanne Aix-Marseille - BP 80, Europole Méditerranéen de l'Arbois, 13545 Aix en Provence, France.

Keywords: North Ligurian margin, ocean bottom seismometers, refraction tomography, velocity structure, crustal units, microseismicity.

\section{Abstract}

20 The deep structure of the North Ligurian margin and its contiguous Ligurian basin as well as the seismicity these zones experience are neither well understood nor precisely constrained. In order to address these questions, there is a need for offshore instrumenting, which was realised for a duration of nearly 6 months, during the GROSMarin (Grand Réseau d'Observation Sous-Marin) experiment. An array of 21 ocean bottom seismometers was deployed over the most active area of the margin and was complemented on land by mobile seismological stations that densified existing permanent networks. We also took this opportunity to realise the acquisition of deep refraction seismic shots at sea in order to get a 3D distribution of velocities along the margin through travel time tomography. We present here a preliminary analysis of the seismicity recorded during this experiment and a tomographic model of the margin's structures obtained using data from the offshore network only. Our results reveal a high velocity zone at the base of the crust on the northern part

30 of the deep basin that is very similar to that observed across the neighbouring margin of the Gulf of Lions and that is most likely related to serpentinisation of the underlying mantle in the late stages of rifting. We also observe the crustal thickening beneath the margin that appears to be progressive in the western part of our study zone and to narrow eastward. In contrast, our velocity distribution does not reveal an E-W transition between two types of crust as other geophysical observables suggest. Some microseismic activity

35 was recorded throughout the duration of the experiment, on land and at sea. The number of detected events and precision of location were both improved by our dense temporary network, although some work remains 
to fully exploit its detection capabilities.

\section{L'expérience GROSMarin : Structure Crustale en Trois Dimensions de la \\ 40 Marge Nord-Ligure par Tomographie d'Ondes Réfractées et Analyse Préliminaire de Mesures Microsismiques}

Mots clés : Marge Nord-Ligure, sismomètres de fond de mer, tomographie d'ondes réfractées, structure de vitesse, unités crustales, microsismicité.

\section{Résumé}

La structure profonde de la marge Nord Ligure et du bassin Ligure contigu, ainsi que la sismicité enregistrée sur ces zones ne sont pas bien comprises ni précisément contraintes. Pour ce faire, il est nécessaire de disposer d'une instrumentation en mer, ce qui a été réalisé durant presque 6 mois dans le cadre du projet

50 GROSMarin (Grand Réseau d'Observation Sous-Marin). Un réseau de 21 sismomètres de fond de mer a été déployé à cette occasion sur la partie la plus active de la marge, complété à terre par des déploiements de stations sismologiques temporaires venant densifier les réseaux régionaux permanents. Cette opportunité a également été saisie pour réaliser des tirs de sismique réfraction profonde afin d'obtenir une distribution 3D des vitesses sur la marge par tomographie des temps d'arrivées. Nous présentons ici une analyse préliminaire

55 de la sismicité enregistrée durant cette expérience et un modèle tomographique des structures de la marge obtenues à partir des seules données du réseau sous-marin. Nos résultats montrent l'existence d'une zone de vitesse élevée en base de croûte sur la partie Nord du bassin profond, similaire à celle observée sur la marge voisine du golfe du Lion et vraisemblablement liée à la serpentinisation du manteau sous-jacent durant la phase tardive du rifting. Nous observons également l'épaississement crustal sous la marge qui apparaît

60 progressif à l'ouest de notre zone d'étude et qui devient plus étroit vers l'est. Par contre, notre distribution de vitesse ne révèle pas une transition de l'est à l'ouest entre deux types de croûte, comme d'autres observables géophysiques semblent le montrer. Une activité microsismique a été enregistrée durant la durée de déploiement. Le nombre d'évènements détectés ainsi que la précision de localisation se trouvent améliorés par notre réseau temporaire dense, bien que du travail reste à mener pour exploiter pleinement ses capacités

65 de détection. 


\section{Introduction}

The North-Ligurian rifted margin is singular in that it lies immediately next to the Alpine orogenic arc (Fig. 1). It has formed in the general context of convergence between the African and Eurasian plates that has seen

70 the subduction of the Tethys Ocean [e.g., Dercourt et al., 1986], the collision and accretion of continental blocks of the Tethyan plate - locally responsible for the Alpine and Appenine orogenies - and some backarc rifting and oceanic spreading. The Ligurian basin is indeed one of these backarc basins related to the rollback of the subduction that now only subsists as the short Calabrian arc and has evolved to collisions elsewhere, along the Appenines and Maghrebides belts [e.g., Faccenna et al., 1997]. It opened with the Corsica-

75 Sardinian counterclockwise block rotation, during Lower Miocene, preceded by an Oligo-Aquitanian rifting phase [Réhault et al., 1984, Speranza et al., 2002, Gattacceca, 2007] that, for its northeastern part, occurred within the Alpine-Northern Appenine collision belt and therefore presumably affected an initially thick crustal continental domain.

The resulting oceanic basin has been shown to feature a low crustal thickness of 5-6 km or less [Pascal et al.,

80 1993, Contrucci et al., 2001], indicative of a slow rate of accretion and/or of somewhat cold backarc mantle temperatures, possibly attributable to the fact that the stretched domain was in part initially a thick intrabelt zone [Chamot-Rooke et al., 1999]. The thin crust in the oceanic basin is overlain by an equivalent thickness of sediments, divided into deep Miocene units, massive evaporitic units (primarily salt, 1-2 km thick) precipitated during the short Messinian salinity crisis, and Plio-quaternary deposits on top [Contrucci et al.,

85 2001]. This makes the oceanic crust inaccessible to direct observation and sampling - even through drilling and also hardly investigated by means of conventional reflection seismics, due to the screening and diffracting effects of the salt diapiric units. The lack of clearly coherent magnetic anomalies also characterises this atypical oceanic domain [Bayer et al., 1973, Galdéano and Rossignol, 1977, Rollet et al., 2002]. It is flanked by the two asymmetric Ligurian and Corsican margins. The North Ligurian margin

90 exhibits a fairly narrow structure, with no shelf and a strong bathymetric gradient that is continued onshore, up to the $3000 \mathrm{~m}$-high Argentera massif - there is less than $70 \mathrm{~km}$ between this massif and the $2500 \mathrm{~m}$ isodepth that roughly marks the limit of the oceanic basin. Seismic imaging reveals an upper crustal rifted structure comprising only two major 15-20 km-wide tilted blocks [Rollet et al., 2002]. The syn- and postrift units above have been truncated by the intense Messinian erosion that has levelled the structures inherited 
distinguished along strike and correlate with the neighbouring geological Hercynian and Alpine structures observed onland. These land geological domains are in correspondence on both rims of the basin [Rollet et al., 2002]. This reflects the strong structural inheritance on the processes that controlled the formation of these margins. Separating the oceanic domain from the stretched continental structures are transitional

100 domains, identified on the basis of various geophysical signatures of the basement [Pasquale et al., 1994, Gueguen, 1995, Contrucci et al., 2001, Rollet et al., 2002]. On the northern margin, the width of this interpreted transitional domain decreases northeastward from $\sim 50 \mathrm{~km}$ to essentially zero east of the Italian border. It shall be noted that the limits between the domains vary between authors. The nature of crustal material is uncertain for the transitional and oceanic domains wherein partly serpentinized mantle ultramafics

105 are likely to be incorporated in unknown proportions [Pascal et al., 1993, Contrucci et al., 2001, Rollet al., 2002]. The seismic structure of crustal domains in the northeastern part of the Ligurian sea is essentially known through 1D expanding spread profiles [Contrucci et al., 2001] that only provide localized constraints. The neighbouring conjugate margins of the Gulf of Lions and Sardinia have only recently been explored by OBS profiling and show somewhat symmetric domains, although their widths differ from one side to the

110 other [Gailler et al., 2009].

The North Ligurian margin - unlike its Corsican conjugate - and the southwestern part of the Alps experience a documented seismic activity that evidences some strain (Fig. 1). Geodesy shows some shortening of less than $1 \mathrm{~mm} / \mathrm{yr}$ between Corsica and the Ligurian coast and also between this coastal area and the axial zone of the southwestern Alps [Larroque et al., 2009]. There are two candidates for this

115 deformation: a local cause is the strong altimetric gradient, mentioned above, between the Argentera massif and the deep basin, which would result into downhill gravity collapse whereby strain would focus on structures between the inner Alpine zone and the toe of the North Ligurian margin [Béthoux et al., 2008]; the alternative explanation implies the broader scale convergence motion between Africa and Eurasia, some residual part of which would be accommodated on the margin and reactivate it in a compressive mode 120 [Larroque at al., 2009], possibly through the differential motion of the Apulian block [Béthoux et al., 1992]. The seismotectonics of the area is coherent with the picture provided by geodesy. Extensive focal mechanisms are being observed in the Argentera massif and compressive ones in the Northern part of the Ligurian basin [Béthoux et al., 1992, Baroux et al., 2001, Larroque et al., 2009] with a few strike slip mechanisms. More generally, the southwestern Alps and northern part of the Ligurian basin are subject to 
125 frequent earthquakes of low to moderate magnitudes and significantly destructive events are known to have occurred in the past and represent a non-negligible threat to an area that has quickly urbanised and whose population has grown dramatically during the last century. Among several historical events [Larroque et al., 2001], the 1564 and 1887 earthquakes stand out as the most destructive; the latter occurred offshore Italian Liguria, triggered a tsunami and resulted in more than 600 casualties. Apart from these rare large events,

130 regional studies agree in concluding that the important local microseismicity appears to be poorly focused [e.g., Courboulex et al., 2007] and that, if some tectonic lines are documented onland [Courboulex et al., 2001], the active structures at sea remain unknown. It is therefore an essential prerequisite to gain better insight into the deep seismogenic structures along the North Ligurian margin and even farther offshore, in the identified oceanic domain, since some seismic activity including large events [Réhault and Béthoux,

$1351984]$ is recorded in the northern half of the Ligurian Sea.

It is a crucial issue to determine whether the observed diffuse activity (Fig. 1) is related to the absence of clearly mature structures that would focus strains or if some imprecise relocation of events would lead to this scattered pattern. The fact that some of these structures can undergo ruptures of $\mathrm{Mw} \sim 6.5$, such has the 1887 event [Bakun and Scotti, 2006], suggests that at least to some extent, instrumental insufficiencies in the 140 detection and location of microseismicity is a limit to identify developed active faults that have not known large instrumented ruptures to date.

One clear reason of instrumental bias in the recording of local seismicity is the irregular coverage provided by regional seismic networks. Permanent instruments are naturally limited to land areas and fail to clearly constrain the seismic activity offshore. Considering the specificity of the regional dynamics (low strain rates,

145 rare large events and a regular seismic activity limited to small events with $\mathrm{M}<3-4$ ), even the seismicity recorded on land is affected by insufficient coverage provided by permanent networks; as a consequence, it requires temporarily densified instrumenting by mobile stations, as shown by the SALAM experiment [Courboulex et al., 2007]. The problem is even more acute at sea where the limitation is not simply an insufficient instrumental density, but a strong azimuthal bias with only a one-sided recording by remote 150 coastal stations.

Considering the potential threat of strong offshore earthquakes, it is essential to characterize faults that are prone to rupture in order to quantify associated seismic and tsunami hazard. Assuming some weak seismicity exists along these faults that remains undetected by onland networks, some marine stations are necessary to 
address instrumental remoteness, to record and locate marine microseismicity, and to delineate active structures. Recent developments in sea bottom seismic instrumentation have focused on augmenting the duration of immersion of instruments and fitting them with sensors of increased bandwidth in order to extend their capabilities to the passive recording of seismicity and teleseismicity (these instruments being historically developed for wide-angle seismics purposes). The availability of these new generations of ocean bottom seismometers (OBS) exactly addresses the need for long marine recordings we have here in the

160 Ligurian area. This prompted the GROSMarin (“Grand Réseau d'Observation Sous-Marin") project, which basic principle consists in a $\sim 6$-month deployment of an OBS array above the zones of the North Ligurian margin and contiguous basin that have a documented activity, in order to decrease the detection threshold and to reach detection distances that provide a good location of events and possibly, focal mechanisms.

The strong structural heterogeneity of the Ligurian domain, inherited from its complex geological history,

165 has prompted conjectures that structural contacts would be natural candidates for the accommodation of local deformation [Béthoux et al., 2008]. Hence, finding active zones and characterising the extent of the main crustal units in the area are quite likely intricate problems. The GROSMarin project was therefore designed to address both issues, taking the opportunity of the OBS array deployment to perform seismic shots so as to obtain the distribution of seismic velocities inside the covered zone, by means of 3D tomography based on

170 active data. Finally, the recording array was complemented by the installation of land mobile stations in order to densify the permanent networks and to have homogeneous recording conditions over the whole instrumented area. The sea and land networks are in direct continuity. They spread on both sides of the French-Italian border and span a roughly rectangular zone of $100 \mathrm{~km}$ by $50 \mathrm{~km}$ in NW-SE and NE-SW directions respectively (Fig. 2). The permanent stations outside of this rectangular zone extend the array but

175 with less instrumental density. The GROSMarin marine cruise - part of the project as a whole - was devoted to the deployment of OBS's and to the realisation of seismic shots.

In this study, we present the details of our acquisition and first results of a 3D tomography of crustal seismic velocities obtained by inversion of first arrival travel times extracted from active seismic data recorded by our OBS array only. Some preliminary results obtained from the analysis of microseismicity during 5-month passive recording are also presented. We subsequently interpret and discuss these results.

\section{Data acquisition}


Deployments of ocean bottom seismometers were carried out at the beginning of the marine cruise, onboard R/V l'Atalante, on 20-21 April 2008. The deployed array of OBS's comprised three types of instruments: ten recently developed stations of the Geoazur pool, six older instruments, of UTIG design, from the same pool and five instruments from KUM/IFM-GEOMAR featuring gimballed broadband sensors. All these instruments were fitted with 3-component geophones and a hydrophone. A total of twenty one stations was thus deployed, of which fifteen were left for the whole duration of the passive recording phase - the six UTIG-type instruments were retrieved after about two months, due to their limited autonomy. All intermediate and final recoveries were carried out from R/V Tethys II, on 29-30 June and 2-5 October 2008. Three instruments were reported missing after the June recoveries but two of these were later retrieved and handed back after being found drifting. Three other instruments also failed to be released back during October recoveries, bringing the number of losses to 4 stations. These lost stations occupied slots $6,10,13$ and 19 (Fig. 2) for which we therefore have no data.

195 The ocean bottom stations were deployed along a $37.5 \times 50 \mathrm{~km}$ rectangular grid parallel to the margin, with a square mesh of $12.5 \mathrm{~km}$. One slot was left empty close to the coast due to last minute problems on one of ours OBS's and two instruments extending the network $12.5 \mathrm{~km}$ seaward were placed out of this box, in continuation along two margin-perpendicular axes of the grid (Fig. 2), in order to record potential events that would occur farther offshore, as historical seismicity shows to happen. This geometry results from a trade off

200 between the number of stations available, the necessity to encompass active areas as much as possible and that of keeping sufficiently small distances between stations to ensure a precise relocation of events and an acceptable resolution to the $3 \mathrm{D}$ tomographic model to be derived from the active data.

Our recording array is complemented on land by the permanent regional velocimetric and accelerometric stations of the French (ReNaSS and RAP) and Italian (RSNI) networks which offer an extension to our grid 205 of OBS's. However, the density of these networks is insufficient to offer recording distances comparable to those of the marine array. Therefore, thirteen 3-component portable velocimetric land stations were deployed on land (six in Italy, seven in France), up to $30 \mathrm{~km}$ North from the coast, to even network densities. Where possible, these temporary stations were disposed in continuity with the NNE-SSW lines of OBS's. The temporary part of the land network was left for the same duration as its marine counterpart.

210 After the initial OBS deployments, seismic shots were fired from a deep refraction seismic source towed by $\mathrm{R} / \mathrm{V}$ l'Atalante. The route followed while shooting is coincident with the cartesian directions of the OBS 
array (Fig. 2), yielding the acquisition of five $\sim 105 \mathrm{~km}$-long lines across the margin and four $\sim 165 \mathrm{~km}$-long lines along - the landwardmost actually shorter due to the concavity of the coast. The geometry of acquisition and planned tomography being 3 dimensional, shots kept on being fired while joining profiles,

215 providing additional directions of coverage, in particular along the $\sim 75 \mathrm{~km}$-long oblique profile that joins the series of margin-perpendicular to margin-parallel profiles. Likewise, it can be noted that the two landwardmost WSW-ENE profiles include significant departures from the theoretical straight route due to the presence of drifting fishing nets, which is not an issue for 3D analysis. Lines are numbered sequentially according to the acquisition sequence: lines 1 to 5 are perpendicular to the margin, from West to East; line 6

220 is the oblique line at the southeastern end of our study area and lines 7 to 10 are oriented along-strike, from the basin to the coast.

The seismic source was designed to enhance signal propagation over long distances as a means to record exploitable deep-refracted waves. An array of eight 16-L and two 9-L Bolt airguns was mounted and towed between 20 and $30 \mathrm{~m}$ depth to provide the strong and low frequency signal necessary for deep crustal

225 investigation. Shot interval was one minute, necessary both to recharge the airguns at the nominal pressure of 140 bar, and to avoid overlapping between phases of consecutive shots. All the lines but one were acquired in "single bubble" mode, that is, with a synchronization of the different airguns on their first bubble oscillation [Avedik et al., 1993] to enrich the spectral content of the signal in long-range travelling low frequencies. Considering the characteristics of this array, it turned out that triggering all airguns simultaneously would be

230 at little expense for the low frequency content but would improve the impulsivity of the signal and hence, would make phase pickings somewhat more accurate. As an attempt to make a comparison, one of our profiles was acquired with this airgun tuning and resulting data show little differences in terms of detection distances. This analysis should however be complemented by an examination of long-distance land recordings, which is beyond the scope of this study.

235 The study area happens to lie just in the Pelagos sanctuary for marine mammals in western Mediterranean, which implied certain precautions in our using strong acoustical signals emitted by the refraction seismic source. Observers onboard the boat checked that no individuals of the protected species found themselves in a harmful range from the source. In practice, there was little impact on the completion of our operations. The microseismicity has been recorded by all twenty one OBS's initially deployed for 2 months, and fifteen remained operational for three and a half more months, to final recoveries. The land network was operational 
during the whole period.

\section{Seismic tomography from refracted arrivals of shots}

Recorded data were corrected from clock drift. The two instruments that were recovered after a long drift at

245 the surface had no reliable time skew measurements; two other instruments also failed to provide skew figures after recoveries. These four instruments were all fitted with clocks for which ignoring the time drift could be significantly detrimental to the quality of travel time measurements. We therefore had to perform independent laboratory measurements of their drifting rate in temperature conditions similar to those found at the sea bottom and extrapolate measured values to their duration of immersion. We checked the validity

250 and precision of the procedure by comparing arrival times after clock corrections for water wave arrivals of the two crossing lines that pass above each of the concerned instruments. Since there was a lag between the acquisition of these margin-parallel and margin-perpendicular profiles, any incorrect time localization would have resulted in differences between water arrivals for each of these lines, which we found out not to be the case within the precision of our time picking.

255 The data corresponding to the period of active seismic shots were merged with the acquisition file to make seg-y files suitable for wide-aperture seismic data analysis. For each OBS, the single file corresponding to the shooting route was then cut according to the followed lines in order to allow for a line-by-line examination of arrivals; bandpass filtering and velocity reduction were applied before proceeding with manual picking of first arrival refracted phases. These first arrivals picks were gathered in subsets that

260 showed good trace-to-trace coherency and an homogeneous signal to noise ratio; each subset was consequently assigned a picking uncertainty through visual assessment. These uncertainties range from 20 to $200 \mathrm{~ms}$. A total of 47,939 travel times have been picked from the seventeen ocean bottom instruments that were recovered.

It is important to avoid that possible errors on actual instrument location on the sea bottom transfer to the

265 velocity model. We therefore performed an OBS relocation procedure based on a systematic inversion of picked direct arrival times (water wave). More precisely, every possible position of the OBS on the sea bottom was tested on a square area of $0.5 \times 0.5 \mathrm{~km}$ centred on the surface deployment position with increments of $25 \mathrm{~m}$ in each directions. Water velocity was also included in the inverse problem and best fitting results were obtained with velocities around $1530 \mathrm{~m} \cdot \mathrm{s}^{-1}$, a value that was adopted in subsequent 
tomographic inversions. Practically, RMS misfits for these direct arrivals were brought down to a few ms for the best-fitting positions, that is, to about the precision of our water wave picking.

In order to perform tomographic inversion of the picked travel times, a local cartesian reference system was defined through local Mercator projection followed by a rotation to have grid axes in the same directions as the lines of our OBS grid - the margin-perpendicular axis is oriented $\mathrm{N} 337^{\circ}$. A tomographic box was thus

275 created that encompasses all our acquisition geometry (Fig. 3). The dimensions of this box are $182 \times 120 \mathrm{x}$ $30 \mathrm{~km}$; the vertical dimension of $30 \mathrm{~km}$ ensures that the deepest modelled refractions lie well within the limits of the model for velocity gradients found on margins or oceanic basins. A compilation of local 25 and $50 \mathrm{~m}$ multibeam bathymetric grids was made to get an accurate interpolated bathymetry inside our frame. The tomographic approach we use here is a linearised algorithm in which the inverse problem of first arrival

280 travel time misfits is solved iteratively with added constraints to keep some smoothness to the model and avoid velocity perturbations from being added solely along thin ray trajectories [Zelt and Barton, 1998]. Rays are calculated by backpropagation through travel time maps that are calculated by a finite difference Eikonal solver [Hole and Zelt, 1995]. The approach requires a starting model that ensures convergence of the inverse problem toward a minimum that corresponds to the model for which the best fit is obtained. In practice, we used a layered model of realistic and continuous velocities increasing linearly with depth on top of which bathymetric variations are added, which fulfils the condition for convergence. The results we present here were obtained after ten non linear iterations within each of which three linearised iterations were performed to seek for the best weighting coefficients of regularization constraints. For forward modelling of travel times, a $0.4 \mathrm{~km}$ cubic mesh was used whereas cells of $2 \times 1.6 \times 0.4 \mathrm{~km}$ were used to parameterise the 290 inverse grid.

The model obtained from tomography is shown in figures 4, 5 and 6, presented as series of vertical slices (both along strike and perpendicularly) and horizontal slices. We limit our display to the zone covered by our OBS array, delimited by a dashed line in figure 3. Out of this zone, the lack of instrumental coverage results in biases in the reconstructed velocities due to the absence of constraints on the shallow structure, stemming 295 itself from the absence of short offset data. The features of this tomographic model are described and interpreted hereinafter, in the "discussion" section.

Some tests that we do not present here were performed in order to establish the robustness and reliability of our 3D velocity structure. Analogous inversions were carried out starting from different initial models 
featuring either higher or lower velocity gradients (oceanic and continental affinity respectively) in order to

300 check the ability of the inversion to produce final models comparable to the model we present here and thus to validate it. This test shows that good constraint on reconstructed seismic velocities is only obtained inside our receiver array, which is no surprise considering that the lack of short offset data prevents reconstruction of shallow velocities outside of the array. A second series of tests that have to be done prior to interpreting velocity structures are the classical checkerboard tests that help precise what size of heterogeneities are

305 resolvable, and therefore interpretable. These tests show that heterogeneities of 5-10 km wavelength or more can be retrieved at depths lower than $5 \mathrm{~km}$ and that anomalies beyond $10-20 \mathrm{~km}$ can be retrieved at greater crustal depth. This result is indeed consistent with our sampling of rayfields by OBS's spaced $12.5 \mathrm{~km}$ apart.

\section{Seismicity}

310 The passive part of recorded data have been preliminarily analysed. Seismicity unfortunately turned out to be low during the period of measurements. A first set of 160 events was determined from the catalogues of local permanent networks. A trigger procedure has been applied to the data of the coastal stations of the dense network on the Italian side and increased the number of detected events to 218 , that is, $\sim 36 \%$ more than what permanent networks alone had allowed to detect. This is a clear illustration of the improved ability to

315 detect small events with a local dense network. It should also be noted that a trigger analysis is yet to be carried out on the majority of our temporary stations and should lead to a significant increase of the detection rate as compared to the number of events evidenced by the permanent networks.

Data segments corresponding to this first catalogue of 218 quakes were extracted on all our land and sea stations and have been formatted in a SEISAN-format data base [Havskov and Ottemöller, 2000] that will be

320 complemented as seismicity analysis proceeds. These extractions were used to perform manual picking of arrivals. Resulting travel times have been used for a location of events [Klein, 1985], using a local 1D optimized model [Eva et al., 2001]. From a qualitative point of view, the location of events was improved with respect to the solutions obtained using only the permanent regional stations, especially hypocentral depths determination.

325 Ocean bottom recordings are as usual characterized by a lower signal to noise ratio than land stations, due to various sources of noise in the water column and poorly controlled coupling of the instruments on a muddy solid surface. Yet, our sea bottom array detected 60 out of the 160 events identified with permanent land 
stations (37.5\%). The figure goes up to 72 if one considers the more complete catalogue of 218 events detected with a subset of mobile stations ( $33 \%$ ). Naturally, all these land-recorded events are more often located on land, which partly explains why they are comparatively less well detected by the sea stations. One may expect that the reverse is true and that microseismicity at sea that goes unnoticed by land stations will be better characterized by nearby ocean bottom instruments when their data are fully analysed.

\section{Discussion}

335 Tomographic models based on inversion of first arrival travel times are inherently of low resolution. The resolution tests described above provide the scales at which velocity features are interpretable. In the forthcoming developments, we will describe anomalies that we locate with $\mathrm{x}$ and $\mathrm{y}$ coordinates which correspond to our local reference system with $\mathrm{x}$ describing the horizontal direction (along strike) and $\mathrm{y}$ the vertical one (perpendicular to strike).

340 Our results show a variability in the distribution of velocities that is mainly oriented perpendicular to the margin, as expected. We can locally correlate our results with some expanding spread profiles that were acquired in our study area [Le Douaran, 1984, Contrucci et al., 2001] and are located on figure 3. ESP 229 (Fig. 7a) shows some very good agreement with the profile extracted from our 3D model at the coincident location, in the upper left part of our model; the only discrepancy is a zone of slightly higher tomographic

345 velocities around $9 \mathrm{~km}$ depth as compared to corresponding interval velocities in the ESP analysis. ESP 224 (Fig. 7b), which is located farther offshore, shows good agreement down to $8 \mathrm{~km}$ depth but exhibits velocities significantly superior to those of our model underneath. We discuss this point below. Our tomographic profiles are naturally smoother than ESP profiles which are parameterised as a stack of constant or quasi-constant flat velocity layers but average values fit generally pretty well, except where indicated just

350 above.

The shallow sedimentary velocity structure revealed by the $3 \mathrm{~km}$ deep horizontal slice (Fig. 6 ) correlates nicely with the the bathymetry (Fig. 2). It can be noted that the $4 \mathrm{~km} \cdot \mathrm{s}^{-1}$ isovelocity contour in the upper part of the model coincides with the toe of the margin's slope. Still at $3 \mathrm{~km}$ depth, we observe a striking correlation between a fast velocity anomaly in the upper left part of our model $(65 \mathrm{~km}<\mathrm{x}<90 \mathrm{~km}, 65 \mathrm{~km}<$ $355 \mathrm{y}<95 \mathrm{~km})$ and the Var river sedimentary ridge which veers from a margin-perpendicular direction to a margin-parallel one just west of our OBS array and whose bathymetric signature vanishes easterly between 
the two seawardmost shot lines of our acquisition (Figs. 2 and 3). These observations show that higher velocities are observed where bathymetry is lower, which can be interpreted as an effect of greater compaction of sediments at a given depth due to a thicker overlying pile.

360 Between 3 and $6 \mathrm{~km}$ depth, one can observe generally lower velocities in the lower right part of the tomographic slices than elsewhere, as shown by the 4 and $4.5 \mathrm{~km} \cdot \mathrm{s}^{-1}$ isovelocity contours. This large zone of comparatively lower velocities diminishes in extent as depth increases. Beyond $6 \mathrm{~km}$ and down to $11 \mathrm{~km}$, there is no clear and coherent velocity variation along strike. This observation is somewhat surprising as a limit from a transitional to an atypical oceanic crustal domain trending approximately perpendicular to the margin by the middle of our box and turning eastward at y $90 \mathrm{~km}$ (Fig. 3) has been proposed, based on subsidence modelling and heat flow measurements [Pasquale et al., 1994], or a variation in seismic reflectivity and facies from the basement top [Rollet et al., 2002]. Indeed the extent of the oceanic domain proposed here by Rollet et al. [2002] matches well the low velocity zone at $4 \mathrm{~km}$ depth described above. This is paradoxical as velocities observed at that depth $\left(4\right.$ to $\left.4.5 \mathrm{~km} \cdot \mathrm{s}^{-1}\right)$ are indicative of deep sedimentary units.

370 Interpretation of ESP229 [Contrucci et al., 2001] indicates that the lowermost Miocene sediments exhibit velocities of $4.4 \mathrm{~km} \cdot \mathrm{s}^{-1}$. We thus precisely lose the supposed crustal pattern as we penetrate the basement. This leaves us with two hypotheses: (1) the crustal transition exists but has little implication in the velocity structure, i.e., rocks of different nature have non-contrasting velocity properties or (2) the geophysical signature on which the recognition of the contiguous domains in this zone was made is indeed of

375 sedimentary origin and not a crustal feature. Further investigation is clearly needed to distinguish between the two.

One tentative explanation for the contrasting velocities in the deep part of the sedimentary pile described above is a variation in the nature of sedimentary deposits. We have little knowledge of the ante-Messinian sedimentary features related to the Var river (due to screening by Messinian evaporites) but we do know that

380 its channel-levee system has migrated throughout Plio-Quaternary from a margin-perpendicular to a marginparallel architecture [Migeon et al., 2000]. Assuming a classical basinward symmetric sedimentary output before Messinian, the limit we observe could mark eastern limit of the Var delta during Miocene. In this hypothesis, the lateral variation in velocities might be explained by a transition from terrigeneous to pelagic deposits.

385 Deeper down in the crust, velocities of 7-7.5 km.s $\mathrm{s}^{-1}$ are encountered between 11 and $13 \mathrm{~km}$ depth for $\mathrm{y}<$ 
$90 \mathrm{~km}$ (Fig. 6). These values are greater than what can be observed in standard continental or oceanic deep crusts. A possible interpretation would be that we are crossing the Moho and that we observe a transition to mantle velocities that is smoothed by our lack of resolution. This view is however at odds with several elements: (1) such high velocities are observed at the base of the crust on ESP 229 [Contrucci et al., 2001] with a Moho reflector underneath (Fig. 7a); (2) analogous ESP analyses [Pascal et al., 1993] as well as tomographic profiles exploiting Moho refections [Gailler et al., 2009] agree with this view of an abnormally fast layer of 2-3 km thickness at the base of the crust across the neighbouring Gulf of Lions margin and its Sardinia conjugate. Besides, similar high deep crustal velocities have also been observed on other rifted poorly volcanic margins [e.g., Chian et al., 1995, Whitmarsh et al., 1996a, Sage et al., 1997, Dean et al.,

395 2000, Thinon et al., 2003, Van Avendonk et al., 2006]. Our results therefore confirm the presence of this high velocity unit at the base of the crust along the North Ligurian margin and help delineate its extent in our study area.

Horizontal and vertical slices perpendicular to strike (Figs. 4 and 6) show that in the upper part of our box, landward of the margin's toe, $7-7.5 \mathrm{~km} \cdot \mathrm{s}^{-1}$ isovelocity contours deepen. We interpret this as a clear evidence 400 of landward crustal thickening and thus show that the latter is correlated with the bathymetric signature of the continental slope. We also note that this correlation is less clear on the western part of our zone where crustal thickening appears to become more progressive and to extend farther offshore. This evolution might be explained by the change in strike of the margin that roughly occurs at the mouth of the Var river (Fig. 2) and that happens to correspond to the limit between the Hercynian and Alpine domains on land [Rollet et al., 405 2002]. East of this incurvation, the margin is actually narrower which could be mirrored in its deep crustal part by a transition to a more abrupt thickening. Further constraints on both sides of our study zone would be help to clarify this inference which provides new insight into the geometry of the Moho below the margin. The high velocity crustal basal anomaly is considered to characterize the transition zone between continental and oceanic domains on the North Ligurian margin [Contrucci et al., 2001], in the Gulf of Lions [Pascal et 410 al., 1993, Mauffret et al., 1995, Gailler et al., 2009] and on several other margins [e.g. Pinheiro et al., 1992, Whitmarsh et al., 1993, Reid, 1994, Thinon et al., 2003, Van Avendonk et al., 2006]. These 7-7.5 km.s ${ }^{-1}$ velocities are intermediate between those of a lower crust - either continental or oceanic - and mantle velocities. They are hence interpreted as serpentinised peridotites resulting from the alteration of the uppermost mantle by water infiltrated at depth during the extensive rifting stage and this interpretation is 
415 even confirmed on the West Iberia margin by rock samples [e.g. Boillot et al., 1989, Boillot et al., 1995, Brun and Beslier, 1996, Whitmarsh et al., 1996b, Pérez-Gussinyé and Reston, 2001, Manatschal, 2004].

More generally, we observe that our velocities are similar to those found in the transition zone of the Gulf of Lions [Gailler et al., 2009], with a strong shallow velocity gradient in the upper $3 \mathrm{~km}$ below seafloor, a much reduced one underneath, down to $8 \mathrm{~km}$ below seafloor, and then again, a marked increase up to the high

420 basal velocities of the crust, discussed above and observed from 10 to $12 \mathrm{~km}$ below seafloor (Figs. 5 and 6). In spite of this analogy between the two margins, there is a noticeable difference in the interpreted structures with regard to the top of the basement: velocities up to $5.3 \mathrm{~km} \cdot \mathrm{s}^{-1}$ are attributed to sedimentary units down to basal Middle Miocene sediments in the Gulf of Lions [Le Douaran et al., 1984, Pascal et al., 1993] whereas in the North Ligurian area, sediments exhibit maximum velocities of $4.4 \mathrm{~km} \cdot \mathrm{s}^{-1}$ only [Le Douaran et al.,

425 1984, Contrucci et al., 2001]. These interpretations rely on coincident multichannel seismic profiling and can therefore be considered well established. The consequence though is that the similarity in velocity distribution does not translate into a similar upper crustal structure. We also infer that the crustal thickness in the transition zone defined as the difference in depth between the Moho and the basement top must be some 2-3 km lesser in the Gulf of Lions as compared to its equivalent on the North Ligurian margin $(\sim 5$ and $\sim 8 \mathrm{~km}$ 430 thick crusts respectively). This significant discrepancy is quite probably related to the difference in rifting conditions, considering that the Corsica-Sardinia rotation pole was located in the gulf of Genova [e.g. Gattacceca et al., 2007] and therefore that extensive strain rates and subsequent basin opening velocity must have been much smaller along the North Ligurian margin than along the more remote Gulf of Lions margin. In both cases though, the resulting structure is characterised by a high velocity lower crust, as described 435 earlier.

One last remarkable feature in our 3D model is the presence of a strong low velocity anomaly in the southern part of the box $(85 \mathrm{~km}<\mathrm{x}<95 \mathrm{~km}, 45 \mathrm{~km}<\mathrm{y}<60 \mathrm{~km}$ ), at depths ranging from 9 to $\sim 14 \mathrm{~km}$ (lower crust). This anomaly is clearly visible inside said range in figures 4,5 and 6 . It lies at a position that is less well covered by the OBS array but its validity is established by the fact that it was reconstructed through different 440 runs of tomographic inversion starting from notably different initial models; in particular, initiating the inversion from a high velocity gradient model not reminiscent of this feature did not prevent it from being retrieved. Velocities within this deep crustal anomaly are $\sim 500 \mathrm{~m} . \mathrm{s}^{-1}$ smaller than in nearby zones at equivalent depth, which is quite likely attributable to a difference in rock types. We note that this anomaly 
coincides with the northern termination of a magnetic anomaly [Rollet et al., 2002], which fully supports the

445 hypothesis of a compositional heterogeneity. We cannot check the correlation between deep crustal velocity and magnetic anomaly further south as we are limited by the coverage of our experiment. However, it also is worth noting that ESP 224 happens to stand exactly at the location of this heterogeneity (Figs. 3 and 6). We propose that the difference in lower crustal velocities that we observe between our velocity log profile and the ESP analysis (Fig. 7b) stems from this local peculiarity: our log profile samples the anomalous zone whereas the ESP-derived log averages the structure along the line shot for the ESP acquisition (in the present case, a $\sim 50 \mathrm{~km}$-long profile parallel to the margin)[Le Douaran et al., 1984], and is therefore poorly sensitive to the anomaly. This view is supported by the fact that another profile extracted from our model nearby the ESP centre, sampled along the line of the ESP but out of the anomalous zone shows a much better agreement with the profile derived from ESP 224 analysis (Fig. 7b).

455 The preliminary analysis of the seismicity recorded during the experiment leads to several observations. A strong activity occurred on the northern part of the Argentera domain $\left(44^{\circ} 10^{\prime}-44^{\circ} 30^{\prime} \mathrm{N}, 7^{\circ} 10^{\prime}-7^{\circ} 35^{\prime} \mathrm{E}\right)$, which is a usual regional pattern and is out of our main topic of interest here. Elsewhere, we observe some events in the foreland area, especially inside the zone our land network covers, with hypocentral depths generally less than $5 \mathrm{~km}$, as already evidenced there by local studies [Courboulex et al., 2007]. Some clusters of shallow

460 events can be observed nearby known tectonic lines such as the Blausasc fault [Courboulex et al., 2007], around $43^{\circ} 45^{\prime} \mathrm{N}, 7^{\circ} 20^{\prime} \mathrm{E}$, and Saorge-Taggia line [Turino et al., 2009] $\left(\sim 43^{\circ} 57^{\prime} \mathrm{N}, 7^{\circ} 48^{\prime} \mathrm{E}\right)$. Another elongated swarm is also revealed further eastward in Italy $\left(44^{\circ} 15^{\prime} \mathrm{N}, 8^{\circ} 13^{\prime} \mathrm{E}\right)$, out of our zone. Some few events are identified at sea, mainly below the continental slope. A large part of these events lie in our network and two small clusters are recorded slightly east of it, offshore Imperia. One event is detected in the basin so far, below the Var channel. Hypocentral depths for these events fall in a 5-15 km range, which is deeper than nearby onshore events.

However, The most important result of this analysis lies in the fact that several events that were identified and located using permanent stations and a part of our temporary network failed to be detected without these mobile stations, especially for five events below the margin. This unambiguously proves that a denser 470 acquisition geometry allows to diminish the detection threshold and to evidence weak events, as already pointed out by Courboulex et al., [2007]. It is important to note that the detection and location of these supplementary events was obtained with data from only a subset of our temporary stations. Performing the 
same kind of analysis with all these mobile devices, in particular the OBS's, should yield a significant increase in the number of detected events.

475 Statistically, it is also important to point out that for those events that were already detected by the regional permanent $\mathrm{n}$ set etworks alone, the addition of data from the temporary stations allowed to reduce error ellipses on hypocenter determinations roughly by a factor of 2 . For events at sea, the error was brought from $\sim 10 \mathrm{~km}$ down to $\sim 5 \mathrm{~km}$ on average.

\section{Conclusion}

Our tomographic investigation of the segment of the North Ligurian margin that experiences the more intense instrumental seismicity reveals that the crustal-scale velocity structure in the landwardmost part of the deep basin is very reminiscent to that observed across the Gulf of Lions margin. It also finds itself in good general agreement with the results of ESP profiling carried out in the same zone and extends the local

485 view provided by these experiments to a wider zone. The most characteristic feature we observe is the high velocity zone at the base of the crust that is most likely related to the presence of serpentinites and that is considered to characterize the transitional zone that separates well identified thinned continental and oceanic domains on several other non volcanic rifted margins and in particular, along the Gulf of Lions margin which constitutes the westward extension of the North Ligurian margin. On this point, we do not evidence an E-W

490 transition from one type of crust to another in our study zone, as other geophysical evidence suggests [Pasquale et al., 1994, Rollet et al., 2002].

Our results also hint that crustal thickening below the margin's slope is more progressive on the western part of our zone than on the eastern one, a feature we tentatively relate to the coincident morphological change of the margin along strike. One may also observe that this change also coincides with the onset of a significant seismicity in the margin and contiguous basin east of the Var river (Fig. 1). The discussion of this points is however left out of the scope of this paper.

Two last observations are (1) that we do not clearly see a transition of crustal structure on the southern end of our tomographic box although velocities seem to hint a decrease of low crustal velocities there. Our seismic coverage on this part of the model that just features one instrument and the limits of the box itself prevent us

500 from being conclusive in that regard, although other studies support the idea that a transition towards the oceanic domain of the basin occurs there [Rollet et al., 2002], at least on the southeastern part of our zone; 
(2) that we observe a seemingly robust low velocity anomaly at the location of ESP 224 that happens to coincide with the northern tip of a mapped magnetic anomaly [Rollet et al., 2002]. Here again, the limits of our box prevent us from fully testing the correlation but some crustal intrusion of volcanic material appears as a plausible explanation to these observations. Volcanic samples in the transition zone around the basin have indeed been correlated with magnetic anomalies.

Among further developments to this work feature the inclusion of land stations data to our travel time data in order to extend our tomographic coverage towards the coast and beyond, and thus to extend our view of the crustal thickening below the margin. A more statistical approach of our tomographic runs and their

510 dependance to the starting model should also help clarifying our constraints on the various velocity structures observed.

As to the seismological part of the programme, the first results presented here confirm that the densified recording of seismicity allows the detection of more events, with an improved location. In particular, the number of events revealed in the margin is significantly increased, although only a small part of the

515 possibilities offered by our denser network have been exploited here. This addresses one of the main goals of the GROSMarin project which is to improve the characterization of seismicity at sea. The immediate continuation of this work is naturally the detection of more events by running a trigger procedure on data from all stations, in particular the OBS's located above active zones at sea. The location of these events is presently made with an average 1D model which is poorly representative of the structural variations across

520 the margin. Using our constrained 3D velocity model from active tomography should yield a much improved determination of hypocentres, complemented by their relative relocation through double-difference techniques [Monteiller et al., 2005]. The objective is to evidence some alignments of events that would delineate active faults and possibly, to correlate these features with seabed structures revealed by the fine bathymetric coverage that has recently been acquired on this margin [Migeon et al., 2009]. It should also be

525 noted that the data extracted from these microseismic events should in turn provide supplementary arrival times and additional directions of rays that might be used to increase our tomographic coverage, hence refining our velocity model and contributing further to this effort of better characterizing the structures of the North Ligurian margin. 
We respectfully salute the memory of recently deceased captain P. Guillemet who, together with his crew of R/V l'Atalante, was instrumental in helping to complete deployments and seismic shots on a tight schedule. These acknowledgements are extended to the crew of R/V Tethys II who were in charge of instrument recoveries. Deployments and recoveries were carried out by Geoazur OBS team (A. Anglade, O. Desprez, Y. Hello) and M. Lefeldt, from IFM-GEOMAR. The members of Genavir technical team were responsible for airgun operations and are thanked for their commitment. F. Klingelhoefer (IFREMER) was of great assistance and advice throughout the cruise, as were D. Scafidi and M. Pavan (Dip.Te.Ris, Univ. Genova). A. Moulins (CIMA Research Foundation) and her team of observers were in charge of warranting the innocuousness of seismic shots on local marine mammals, which they managed to reconcile with the scientific goals of the cruise. E. Flueh (IFM-GEOMAR) made it possible to obtain OBS's from AWI, which was essential for the success of our programme. M. Perrot performed some of the preliminary analysis of seismicity. J. Balestra, D. Brunel, F. Courboulex, A. Dano, Y. Font, L. Honoré, E. Langlois, C. Maron, T. Monfret, G. Nolet, R. Pillet, D. Spallarossa, J. Trévisan and E. Zunino contributed to land stations deployment and servicing. Financial support from Institut National des Sciences de l'Univers, Action Marges programme, Université de Nice-Sophia Antipolis and Conseil Général des Alpes Maritimes helped funding the experiment. This research has also benefited from funding provided by the Italian Presidenza del Consiglio dei Ministri - Dipartimento della Protezione Civile (DPC); scientific papers funded by DPC do not represent its official opinion and policies. The bathymetric and topographic maps displayed in figures were compiled by O. Sardou in the frame of "GIS Curare" project. Some of these figures were made with GMT software [Wessel and Smith, 1995].

\section{References}

AVEDIK, F., RENARD, V., ALLENOU, J.-P. \& MORVAN, B. (1993). - "Single bubble” air-gun array for deep exploration. - Geophysics, 58, 366-382.

555 BAROUX, E., BÉTHOUX, N. \& BELLIER, O. (2001). - Analyses of the stress field in the southeastern France from earthquake focal mechanisms. - Geophys. J. Int., 145, 336-348.

BAKUN, W.H. \& SCOTTI, O. (2006). - Regional intensity attenuation models for France and the estimation of magnitude and location of historical earthquakes. - Geophys. J. Int., 164, 596-610.

560 Mediterranean. - Earth Planet. Sci. Lett., 19, 168-176.

BÉTHOUX, N., FRÉCHET, J., GUYOTON, F., THOUVENOT, F., CATTANEO, M., EVA, C., NICOLAS, M. \& GRANET, M. (1992). - A closing Ligurian Sea? - Pure Appl. Geophys., 139, 179-194.

BÉTHOUX, N., TRIC, E., CHERY, J. \& BESLIER, M.-O. (2008). - Why is the Ligurian basin (Mediterranean sea) seismogenic? Thermomechanical modeling of a reactivated passive margin. beneath rifted margins. - Nature, 341, 523-525. 
BOILLOT, G., BESLIER, M.-O. \& GIRARDEAU, J. (1995). - Nature, structure and evolution of the oceancontinent boundary : the lesson of the west Galicia margin (Spain). - In E. Banda et al. (eds), Rifted Ocean-Continent Boundaries, Kluwer Academic Publishers, 219-229.

BRUN, J.-P. \& BESLIER, M.-O. (1996). - Mantle exhumation at passive margins. - Earth Planet. Sci. Lett., 142, 161-173.

CHAMOT-ROOKE, N., GAULIER, J.-M. \& JESTIN, F. (1999). - Constraints on Moho depth and crustal thickness in the Liguro-Provençal basin from 3D gravity inversion: geodynamic implications. In:

575 DURAND, B., et al., Eds., The Mediterranean Basins: Tertiary Extension within the Alpine Orogen. Geol. Soc. London Special Publications, 156, 37-62.

CHIAN, D., LOUDEN, K.E. \& REID, I. (1995). - Crustal structure of the Labrador Sea conjugate margin and implications for the formation of nonvolcanic continental margins. - J. Geophys. Res., 100, 24 23924253.

580 CONTRUCCI, I., NERCESSIAN, A., BÉTHOUX, N., MAUFFRET, A. \& PASCAL, G. (2001). - A Ligurian (western Mediterranean Sea) geophysical transect revisited. - Geophys. J. Int., 146, 74-97.

COURBOULEX, F, DUVAL, A.-M., DESCHAMPS, A., LOMAX, A. \& LARROQUE, C. (2001). - All the small Peille (Alpes Maritimes, France) earthquake can teach us. - C. R. Acad. Sc. Paris, 333, 105-112.

COURBOULEX, F., LARROQUE, C., DESCHAMPS, A., KOHRS-SANSORNY, C., GÉLIS, C., GOT, J.-
L., CHARREAU, J., STÉPHAN, J.-F., BÉTHOUX, N., VIRIEUX, J., BRUNEL, D., MARON, C., DUVAL, A.-M., PEREZ, J.-L. \& MONDIELI, P. (2007). - Seismic hazard on the French Riviera: observations, interpretations and simulations. - Geophys. J. Int., 170, 387-400.

DEAN, S.M., MINSHULL, T.A., WHITMARSH, R.B. \& LOUDEN, K.E. (2000). - Deep structure of the ocean-continent transition in the southern Iberia Abyssal Plain from seismic refraction profiles: The IAM-9 transect at $40^{\circ} 20^{\prime}$ N. - J. Geophys. Res., 105, 5859-5885.

DERCOURT, J., ZONENSHAIN, L.P., RICOU, L.E., KASMIN, V.G., LE PICHON, X., KNIPPER, A.L., GRANDJACQUET, C. , SBORSCHIKOV, I.M. , GEYSSANT, J., LEPVRIER, C., PECHERSKY, D.H., BOULIN, J., SIBUET, J.-C., SAVOSTIN, L.A., SOROKHTIN, O., WESTPHAL, M., BAZHENOV, M.L., LAUER, J.-P. \& BIJU-DUVAL, B. (1986). - Geological evolution of the Tethys

595 belt from the Atlantic to Pamirs since the Lias. - Tectonophysics, 123, 241-315.

EVA, E. , SOLARINO, S. \& SPALLAROSSA, D. (2001). - Seismicity and crustal structure beneath the western Ligurian sea derived from local earthquake tomography. - Tectonophysics, 339, 495-510.

FACCENNA, C., MATTEI, M., FUNICELLO, R. \& JOLIVET, L. (1997). - Styles of back-arc extension in the Central Mediterranean. - Terra Nova, 9, 126-130.

600 GAILLER, A., KLINGELHOEFER, F., OLIVET, J.-L., ASLANIAN, D. \& SARDINIA SCIENTIFIC PARTY AND TECHNICAL OBS TEAM (2009). - Crustal structure of a young margin pair: New results across the Liguro-Provencal Basin from wide-angle seismic tomography. - Earth Planet. Sci. Lett., 286, 333-345.

GALDÉANO, A. \& ROSSIGNOL J.-C. (1977). - Assemblage à altitude constante des cartes d'anomalies 605 magnétiques couvrant l'ensemble du bassin occidental de la Méditerranée. - Bull. Soc. Géol. Fr., 7(3), 461-468.

GATTACCECA, J., DEINO, A., RIZZO, R., JONES, D.S., HENRY, B., BEAUDOIN, B. \& VEDEBOIN, F. (2007). - Miocene rotation of Sardinia: new paleomagnetic and geochronological constraints and geodynamic implications. - Earth Planet. Sci. Lett., 258, 359-377.

610 GUEGUEN, E. (1995). - La Méditerranée Occidentale : Un véritable ocean, exemple de segmentation des marges et de hiatus cinématiques, implications sur les processus d'amincissement crustal, $311 \mathrm{p}$. - Thèse de doctorat, Univ. de Bretagne Occidentale, Brest, France.

HAVSKOV, J. \& OTTEMÖLLER, L. (2000). - SEISAN earthquake analysis software. - Seismol. Res. Lett., 70, 532-534.

615 HOLE, J.A. \& ZELT, B.C. (1995). - 3-D finite-difference reflection travel-times. - Geophys. J. Int., 121, 427-434.

KLEIN F.W. (1985). - Users guide for HYPOINVERSE, a program for Vax and PC350 computers to solve for earthquake locations, U.S. Geol. Surv., open-file report, 85-515.

620 J., STÉPHAN, J.-F., RITZ, J.-F. \& GILLI, E. (2001). - Active deformation at the junction between southern French Alps and Ligurian basin. - Netherlands J. Geosci., 80, 255-272.

LARROQUE, C., DELOUIS, B., GODEL, B. \& NOCQUET, J.-M. (2009). - Active deformation at the southwestern Alps-Ligurian basin junction (France-Italy boundary): Evidence for recent change from compression to extension in the Argentera massif. - Tectonophysics, 467, 22-34. 
625 LE DOUARAN, S., BURRUS, J. \& AVEDIK, F. (1984). - Deep structure of the north-western

Mediterranean basin: results of a two-ship seismic survey. - Mar. Geol., 55, 325-345.

MANATSCHAL, G. (2004). - New models for evolution of magma-poor rifted margins based on a review of data and concepts from West Iberia and the Alps. - Int. J. Earth Sci., 93, 432-466.

MAUFFRET, A., PASCAL, G., MAILLARD, A. \& GORINI, C. (1995). - Tectonics and deep structure of the north-western Mediterranean Basin. - Mar. Petrol. Geol., 12, 645-666.

MIGEON, S., SAVOYE, B. \& FAUGĖRES J.-C. (2000). - Quaternary development of migrating sediment waves in the Var deep-sea fan: distribution, growth pattern, and implication for levee evolution. -Sedim. Geol., 133, 265-293.

MIGEON S., CATTANEO A., HASSOUN V., LARROQUE C., MERCIER DE LÉPINAY, B., CORRADI,

635 N. \& FANUCCI, F. (2009). -Submarine instabilities along the Ligurian Margin (NW Mediterranean): types, distribution and causes. International Conference on Sea Floor Mapping for Geohazard Assessment (session 4), Forio d'Ischia (Italy) may 11-13, 2009. - Rend. online - Soc. Geol. Ital., 7, 113117.

MONTEILLER, V., GOT, J.-L., VIRIEUX, J. \& OKUBO, P. (2005). - An efficient algorithm for doubledifference tomography and location in heterogeneous media, with an application to the Kilauea volcano. - J. Geophys. Res., 110, B12306, doi:10.1029/2004JB003466.

PASCAL, G., MAUFFRET, A. \& PATRIAT, P. (1993). - The ocean-continent boundary in the Gulf of Lion from analysis of expanding spread profiles and gravity modelling. - Geophys. J. Int., 113, 701-726.

PASQUALE, V., VERDOVA, M. \& CHIOZZI, P. (1994). - Types of crust beneath the Ligurian Sea. - Terra Nova, 6, 255-266.

PÉREZ-GUSSINYÉ, M. \& RESTON, T.J. (2001). - Rheological evolution during extension at nonvolcanic rifted margins: Onset of serpentinization and development of detachments leading to continental breakup. - J. Geophys. Res., 106, 3961-3975.

PINHEIRO, L.M., WHITMARSH, R.B. \& MILES, P.R. (1992). - The continent- ocean boundary off the western continental margin of Iberia-II. Crustal structure in the Tagus Abyssal Plain. - Geophys. J. Int., 109, 106-124.

REID, I. (1994). - Crustal structure of a non volcanic rifted margin east of Newfoundland. -J. Geophys. Res., 99, 15 161-15 180.

RÉHAULT, J.-P. \& BÉTHOUX, N. (1984). - Earthquake relocation in Ligurian sea (Western Mediterranean). - Mar. Geol., 55, 429- 445.

RÉHAULT, J.-P., BOILLOT, G. \& MAUFFRET, A. (1984). - The western Mediterranean basin geological evolution. - Mar. Geol., 55, 447-477.

ROLLET, N., DÉVERCHËRE, J., BESLIER, M.-O., GUENNOC, P., RÉHAULT, J.-P., SOSSON, M. \& TRUFFERT, C. (2002). - Back arc extension, tectonic inheritance and volcanism in the Ligurian Sea, Western Mediterranean. - Tectonics, 21, doi:10.1029/2001TC900027.

SAGE, F., BESLIER, M.-O., THINON, I., LARROQUE, C., MIGEON, S., ANGELIER, J., GUENNOC, P., SCHREIBER, D., DESSA, J.-X., MICHAUD, F., STÉPHAN, J.-F. \& SONNETTE, L. (2010). Structure and evolution of a passive margin in a compressive environment: example of the southwestern Alps - Ligurian basin junction. - Marine Petrol. Geology, submitted.

665 SAGE, F., PONTOISE, B., MASCLE, J. \& BASILE, C. (1997). - Structure of the oceanic crust adjacent to a transform margin segment: the Côte d'Ivoire-Ghana transform margin. -Geo-Mar. Lett., 17, 31-39.

SPERANZA, F., VILLA, I.M., SAGNOTTI, L., FLORINDO, F., COSTENTINO, D., CIPOLLARI, P. \& MATTEI, M. (2002). - Age of the Corsica-Sardinia rotation and Liguro-Provençal basin spreading: new paleomagnetic and Ar/Ar evidence. - Tectonophysics, 347, 231-251.

670 THINON, I., MATIAS, L., RÉHAULT, J.-P., HIRN, A., FIDALGO-GONZALEZ, L. \& AVEDIK, F., (2003). - Deep structure of the Armorican Basin (Bay of Biscay): a review of Norgasis seismic reflection and refraction data. - J. Geol. Soc., London, 160, 99-116.

TURINO, C., SCAFIDI, D., EVA, E. \& SOLARINO, S. (2009). - Inferences on active faults at the Southern Alps-Liguria basin junction from accurate analysis of low energy seismicity. - Tectonophysics, 475, 470-

\section{9}

VAN AVENDONK, H.J.A., HOLBROOK, W.S., NUNES, G.T., SHILLINGTON, D.J., TUCHOLKE, B.E., LOUDEN, K.E., LARSEN, H.C. \& HOPPER, J.R. (2006). - Seismic velocity structure of the rifted margin of the eastern Grand Banks of Newfoundland, Canada. - J. Geophys. Res., 111, B11404, doi: $10.1029 / 2005 \mathrm{jb} 004156$

680 WESSEL, P. \& SMITH, W.H.F. (1995). - New version of the generic mapping tools released. - Eos Trans. $A G U, 76(33), 329$. 
WHITMARSH, R.B., PINHEIRO, L.M., MILES, P.R., RECQ, M. \& SIBUET, J.-C. (1993). - Thin crust at the western Iberia ocean-continent transition and ophiolites. - Tectonics, 12, 1230-1239.

WHITMARSH, R.B., WHITE, R.S., HORSEFIELD, S.J., SIBUET, J.-C., RECQ, M. \& LOUVEL, V. (1996a). - The ocean-continent boundary off the western continental margin of Iberia: crustal structure west of Galicia Bank. - J. Geophys. Res., 101, 28 291-28 314.

WHITMARSH, R.B., SAWYER, D.S., KLAUS, A. \& MASSON D.G. (Eds.) (1996b). - Proc. ODP, Sci. Results, 149. - College Station, TX, (Ocean Drilling Program), 785 p.

ZELT, C.A. \& BARTON, P.J. (1998). - Three-dimensional seismic refraction tomography: a comparison of two methods applied to data from the Faeroe Basin. - J. Geophys. Res., 103, 7187-7210. 


\section{Figures captions}

Fig. 1 - Regional map of the study area and nearby, featuring the seismicity recorded from 1980 to the end of 2009, as provided by the Bureau Central Sismologique Français. The seismic activity is mainly clustered in

695 the Alpine domain and in the northern part of the Ligurian basin. In both domains, it appears to be diffuse at the precision of location allowed by regional seismological networks.

Fig. 2 - Map of the study area with seafloor bathymetry and land topography. The seismic acquisition device used during the GROSMarin experiment is displayed with the following code: permanent and temporary

700 land stations on the French side are noted as red and orange triangles respectively; same distinction on the Italian side with blue and cyan triangles; OBS positions are given by white (AWI instruments), black (geoazur 6-month deployed instruments) and gray (2-month deployed instruments) inverted triangles. The seismic shooting route is indicated by the black line and follow the alignments of OBS's in both directions of the array.

Fig. 3 - Surface map of our tomographic box in the rotated local cartesian reference system used in the inversion. The 17 OBS's that provided exploitable data are displayed with the same color code as in figure 2. Every shot position that provided at least one travel time to the tomographic inversion is represented; the few discontinuities in the shooting route therefore correspond to the shots for which a first arrival could not be

710 reliably identified and picked on any of the OBS's. The dashed square box delineates the zone in which seismic velocities are well constrained by our acquisition and to which we therefore limit the displays of our tomographic model (Figs. 4, 5, 6). The two red stars mark the positions of the ESP profiles [Contrucci et al., 2001] discussed in the text. The yellow line delineates the separation between transitional and atypical oceanic crustal domains, also discussed in the text [Rollet et al., 2002]

Fig. 4 - Profiles cut transversally (perpendicular to the margin) through our 3D tomographic model. The profiles approximately correspond to the transverse shot profiles, where ray coverage is maximum. The horizontal distances correspond to the y coordinate in figure 3; the $\mathrm{x}$ coordinate is fixed and indicated at the lower left corner of each display. The positions of OBS's located along each profile are indicated by grey 720 dots.

Fig. 5 - Profiles cut longitudinally (parallel to the margin) through our 3D tomographic model. As in figure 4 , the displayed profiles approximately correspond to the longitudinal shot profiles. The horizontal distances correspond the $\mathrm{x}$ coordinate of figure 3 with the y coordinate indicated in the lower left corner. The positions of OBS's located along each profile are indicated by grey dots.

Fig. 6 - Horizontal slices cut through our 3D tomographic model at depths indicated in the lower left corner. The depths of these displays are related to features discussed in the text. Surface positions of OBS's are indicated by grey dots.

Fig. 7 - Vertical velocity log profiles at the location of ESP229 (a) and ESP224 (b) [Contrucci et al., 2001]. The profiles derived from ESP analyses and coincident profiles extracted from our 3D tomographic model are superimposed for each site. For ESP224, an additional profile, also extracted from our velocity model at a neighbouring position ( $\mathrm{x}=114 \mathrm{~km}, \mathrm{y}=60 \mathrm{~km}$; see text for details).

Fig. 8 - Preliminary seismicity map of the Southwestern Alps-Ligurian basin zone during the GROSMarin experiment. Circles denote events that were detected and located by the permanent regional land networks in France and Italy. Diamonds mark events detected and located with these networks and some of our temporary stations (see text for details). Solutions for events that were located in both instances are linked by

740 a line. Some epicentres are significantly moved thanks to a better coverage, as are color-coded hypocentral depths. Events that were only located thanks to the partial addition of the temporary stations are those that only feature a diamond with no associated circle. The land and sea bottom stations constituting our composite network are represented respectively as normal and inverted black triangles. 


\section{Figures}

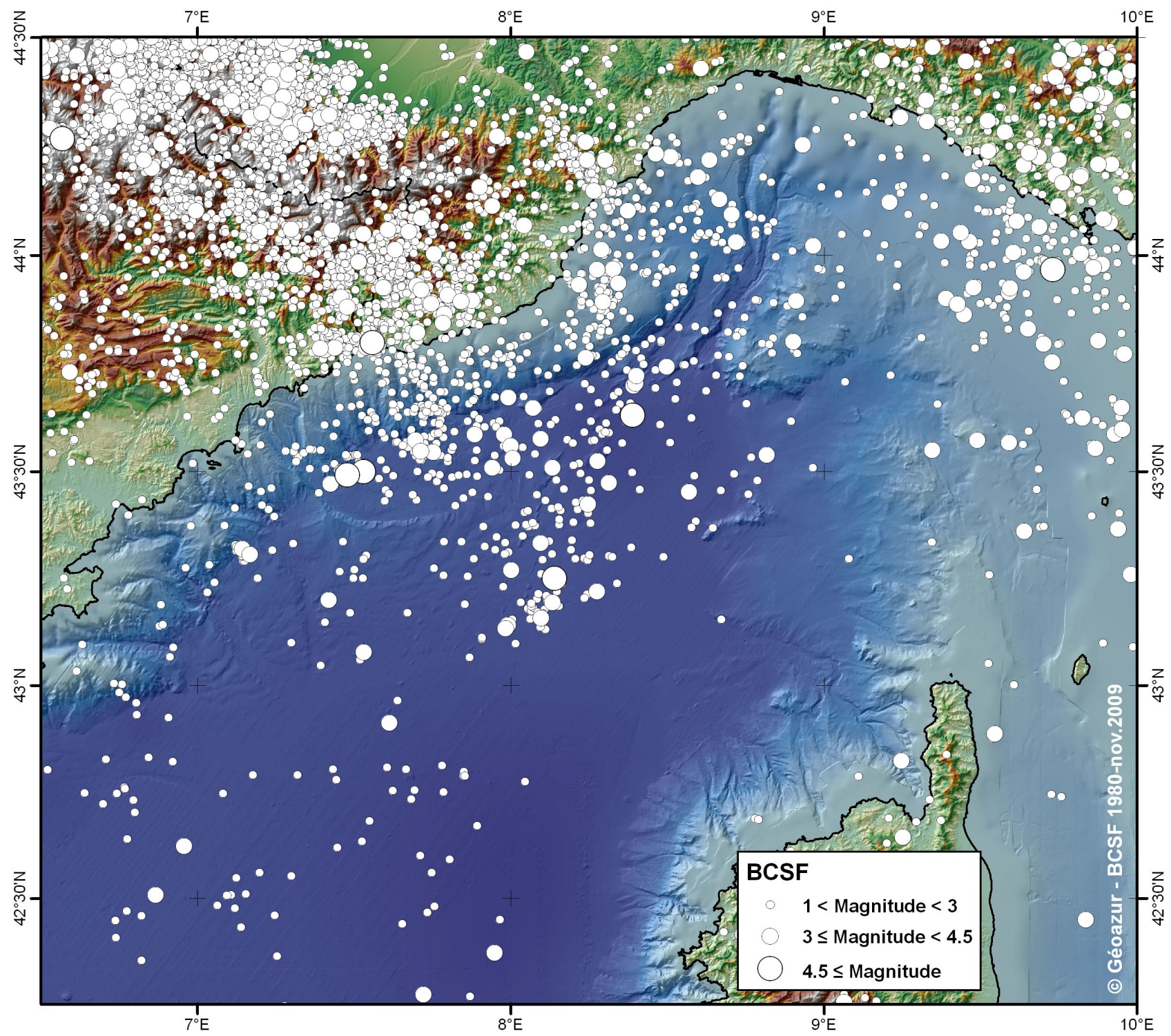

Fig. 1 


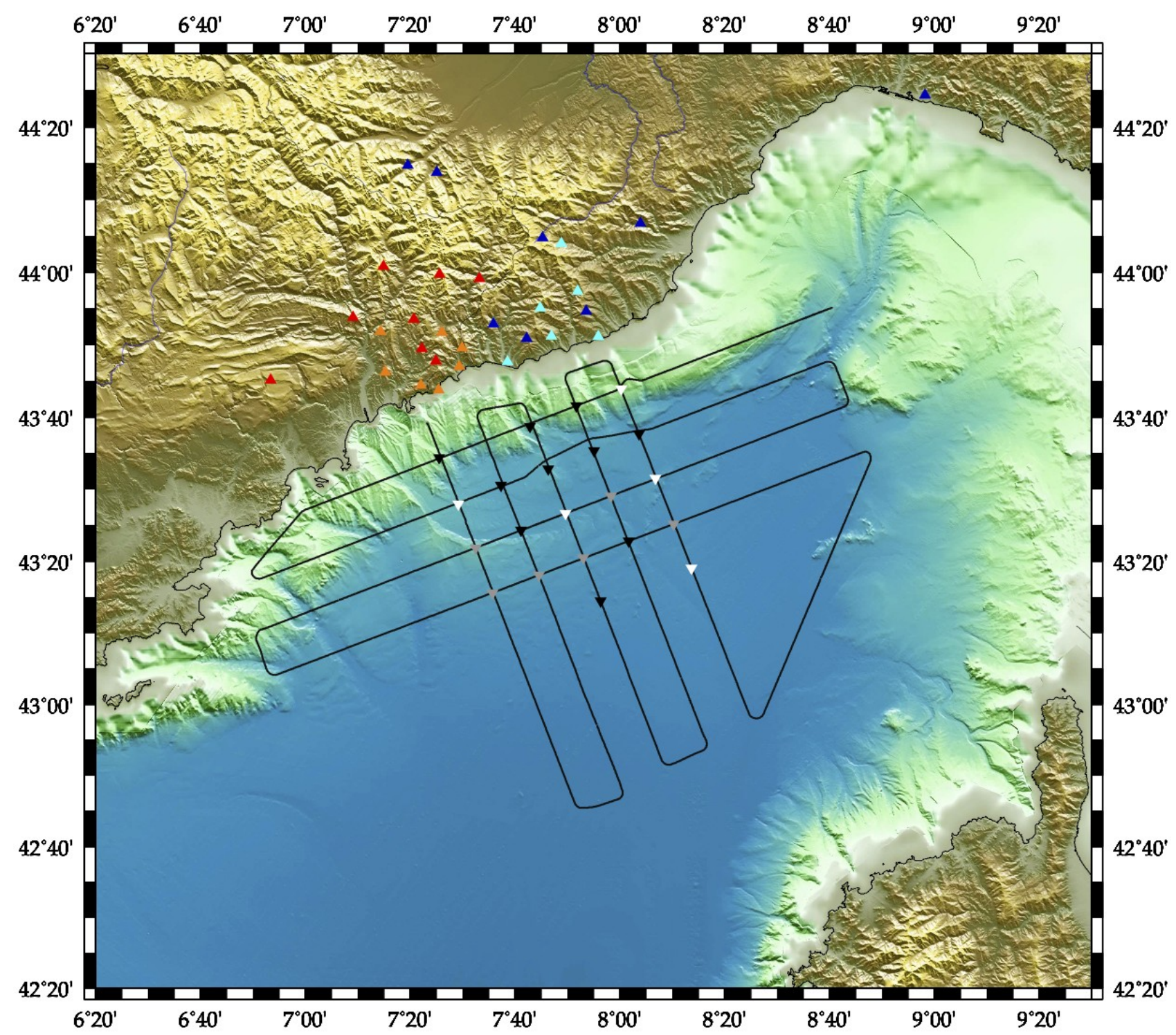

Fig. 2 


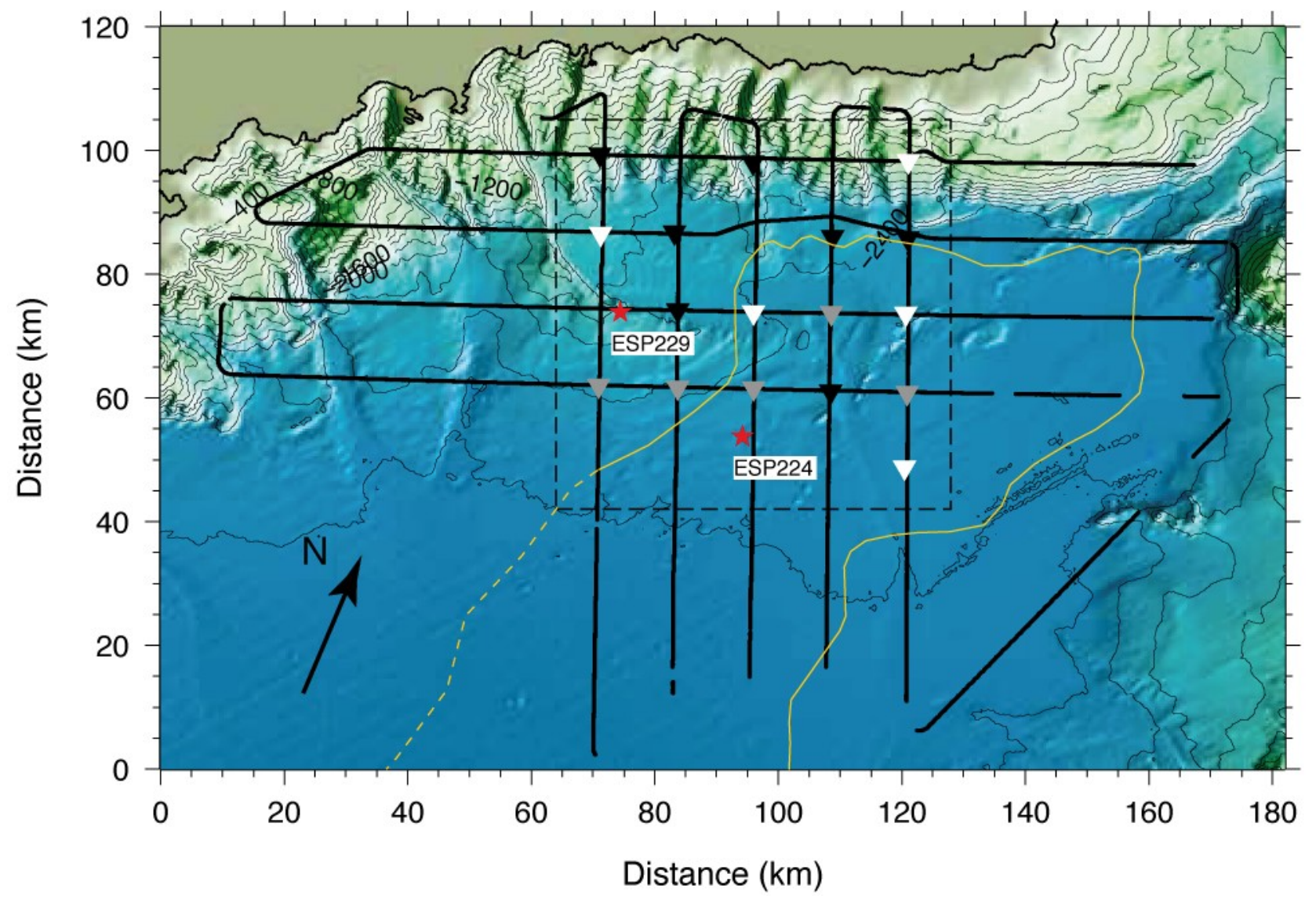

Fig. 3 

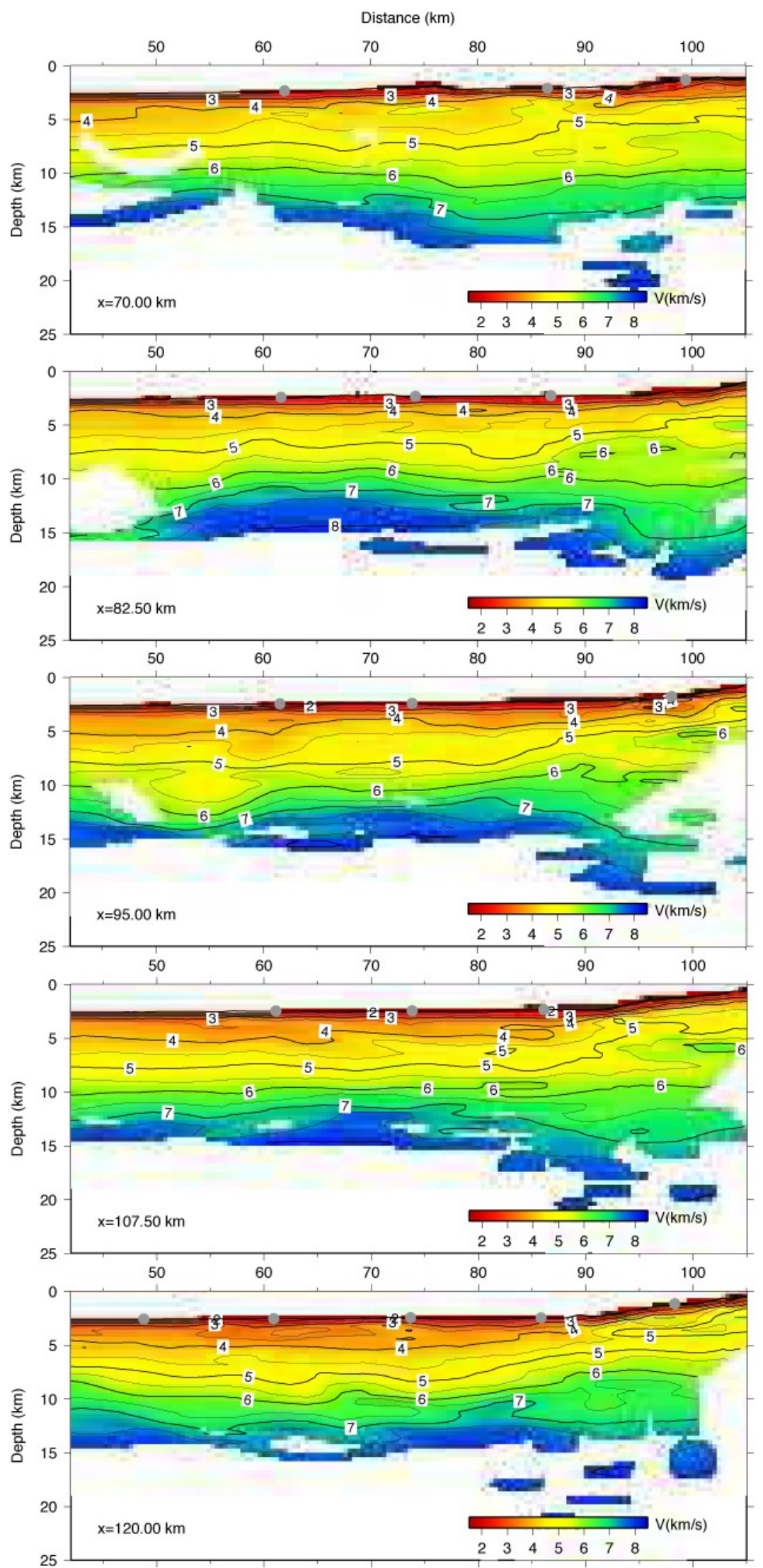

Fig. 4 


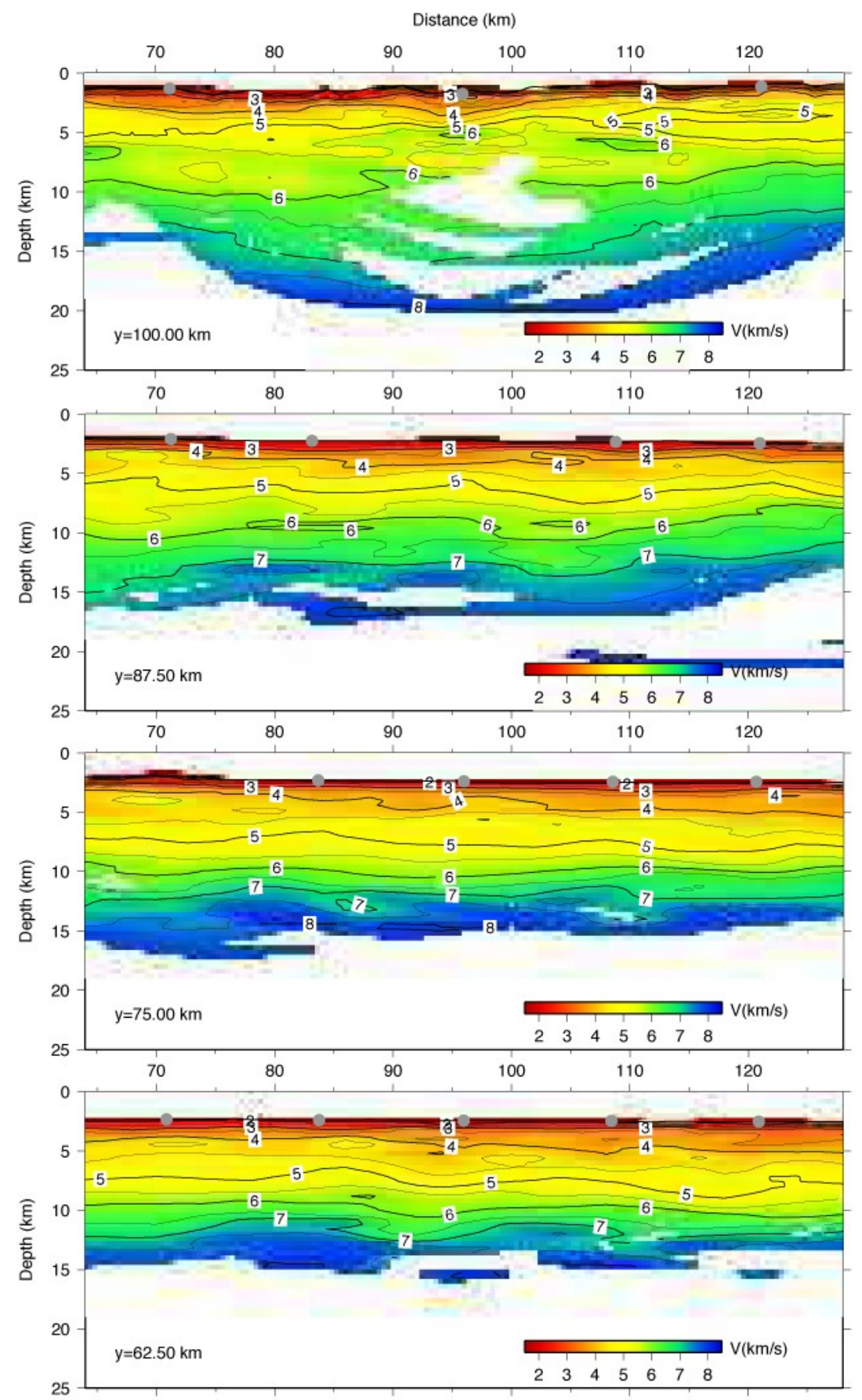

Fig. 5 

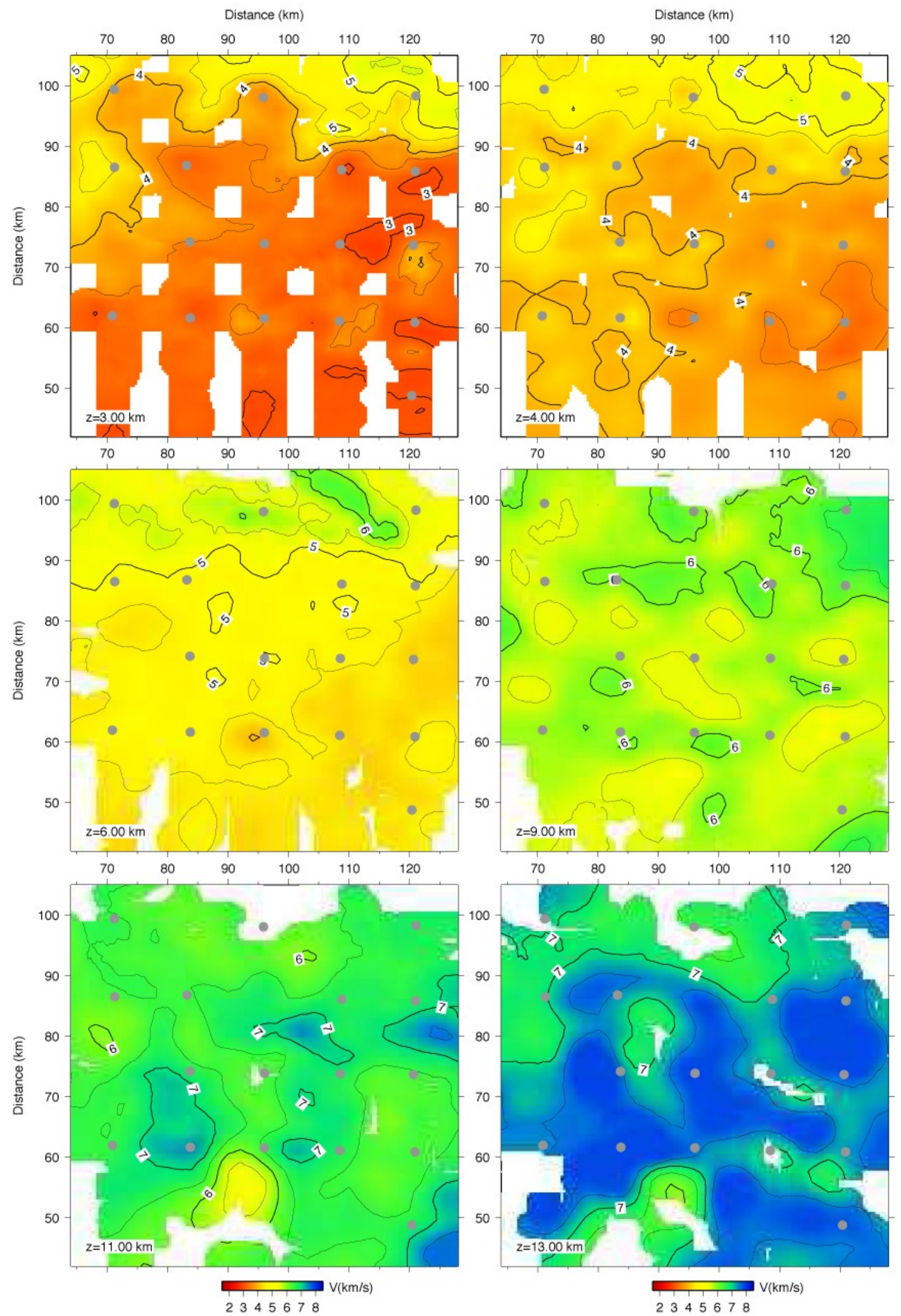

Fig. 6 
a)

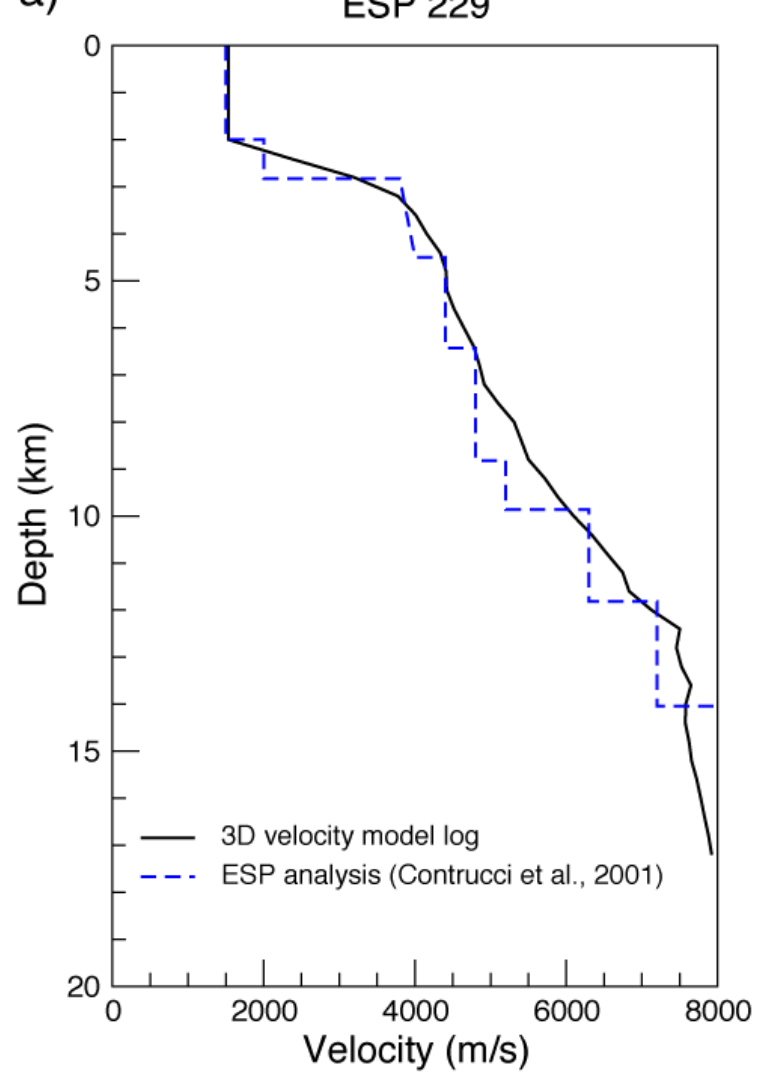

b) ESP 224

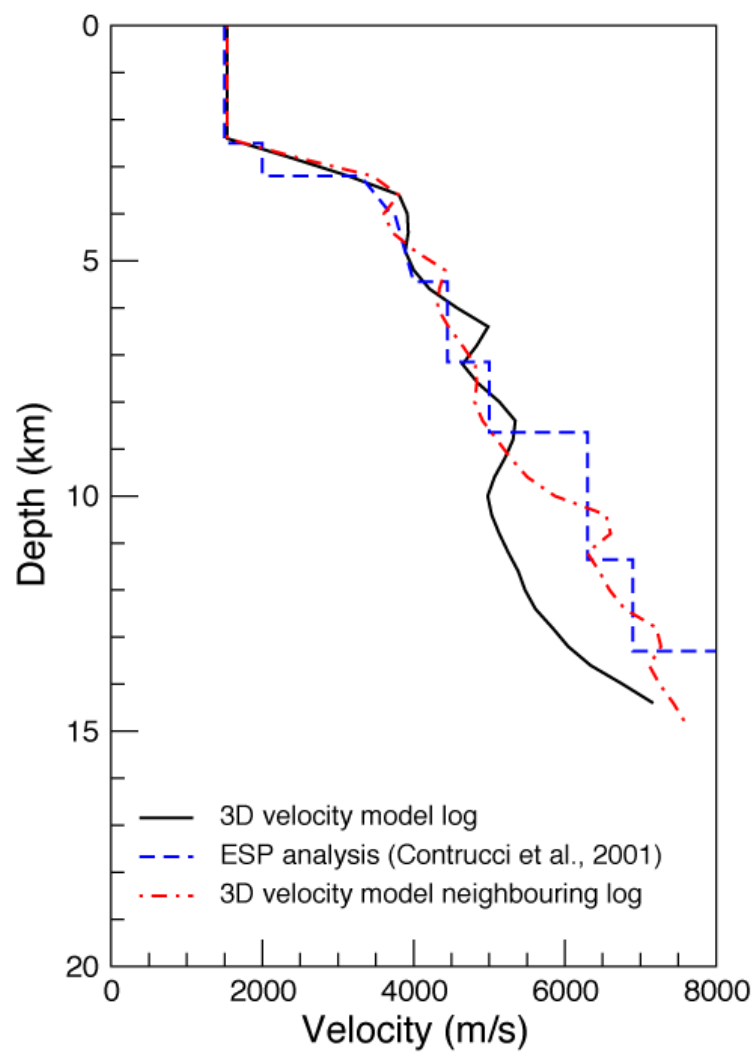

Fig. 7 


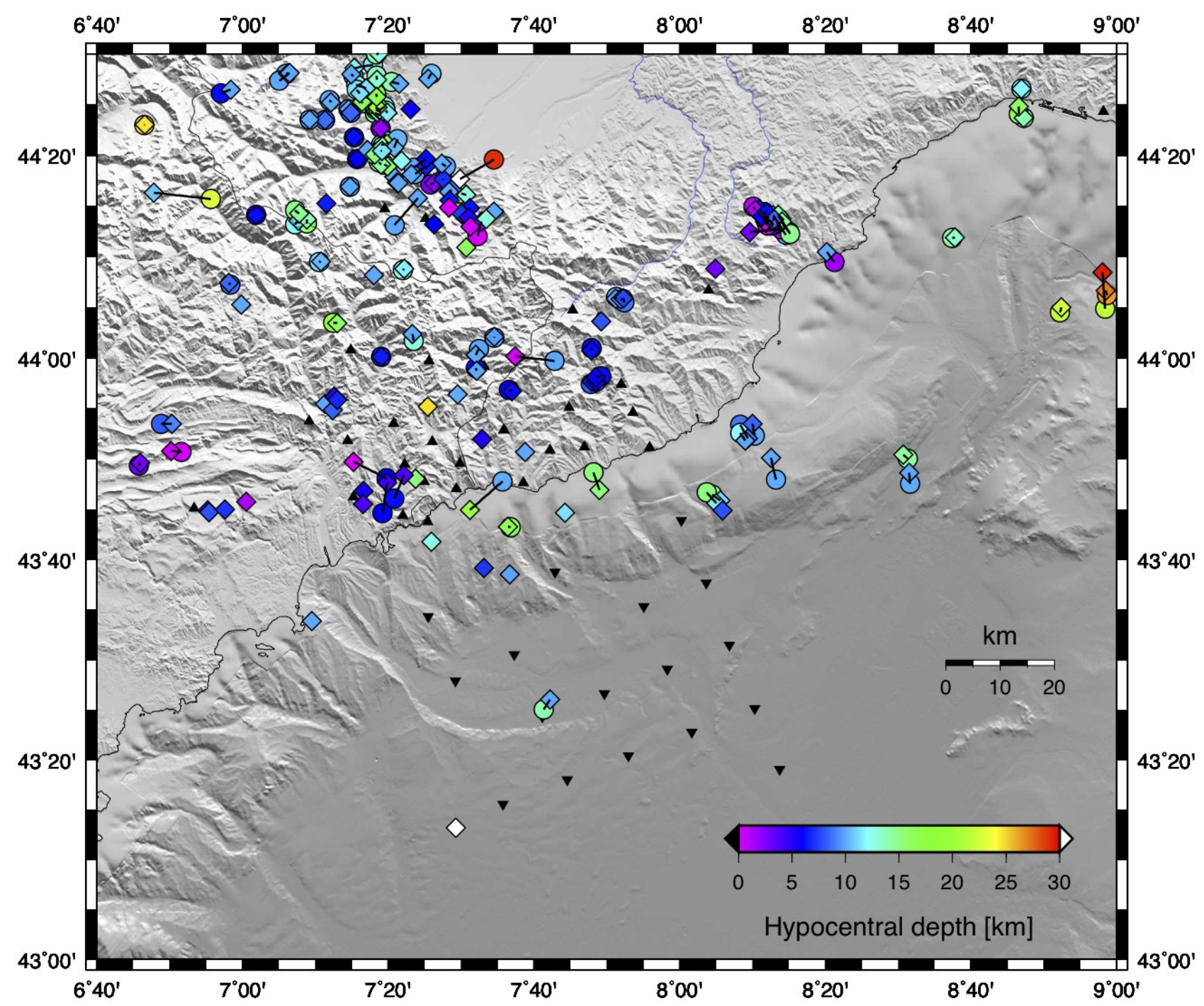

Fig. 8 